\title{
Physicochemical and Microbiological Evaluation of Commercial Tomato Concentrates Consumed In Egypt
}

\author{
Mona, H.H. Bekhet ${ }^{1}$
}

\begin{abstract}
This research was undertaken to determine quality characteristics of twenty four samples of commercial concentrated tomato puree was conducted. Fourteen brands of jar (A), five brands of sachet (B) and five brands of can (C) were evaluated for chemical, physical and microbiological properties. Analysis included each of the following determinations: Total soluble solids, $\mathrm{pH}$ values, titratable acidity, sodium chloride content, ash content, colour, consistency, Howard mould count, total plate count, mould and yeast. Total soluble solids ranged from 20 to $25 \%, 22$ to $25 \%$ and $18 \%$ to $30 \%$ for $A, B$ and $C$, respectively. The $\mathbf{p H}$ values for all types of concentrated tomato puree were below 4.3. Titratable acidity ranged from 1.18 to1.9\% for samples (A), 1.18 to $1.88 \%$ for samples (B) and 1.09 to $2.05 \%$ for samples (C). The sodium chloride content varied from 1.73 to $3.40 \%, 1.94$ to $3.70 \%$ and 0.84 to $2.81 \%$ and ash content ranged from 3.2-5.2\%, $3.83-4.98 \%$ and 2.48-6.06\%, respectively. Colour measured by Hunter Lab Colormeter ranged between1.43 to $2.31,1.51$ to 2.11 and 1.67 to 2.09 a*/b*, while consistency ranged from $5.9-11.9 \mathrm{~cm} / 30 \mathrm{~s}, \quad 7.45$ to $12.67 \mathrm{~cm} / 30 \mathrm{~s}$ and 5.70 to $9.01 \mathrm{~cm} / 30 \mathrm{~s}$, for samples $A, B$ and $\mathrm{C}$, respectively.

Microbial growth could not be detected in all samples with one sachet concentrated tomato puree being the exception. Howard mould content varied between 12-20, 16-24 and12-20\%, for samples $A, B$ and $C$, respectively.
\end{abstract}

Key words: Tomato concentrates, tomato puree, total soluble solids, pH, titratable acidity, $\mathrm{NaCl}$, ash, colour, consistency, Howard count, microbiology.

\section{INTRODUCTION}

Tomato (lycopersicon esculentum) is one of the most popular and widely grown vegetables in the world, at least one third of the tomatoes are consumed in the form of processed products such as tomato juice, paste, ketchup, and puree, etc (Cantarelli et al. 1993, Shao, et al. 2013). In fact, tomato is one of the most important vegetables for the food industry, and its product consumption is large and widely included in human diet (Augusto, et al. 2011, Nisha, et al. 2011).

Tomatoes and tomato-based products are consistently associated with a lower risk of several types of cancer (Grieb et al., 2009, Zhang et al., 2009, Vallverdú-Queralt, et al 2012) and also, to a lesser extent, to a lower incidence of coronary heart disease
(Stahl \& Sies, 2005). All tomato-based products contain micronutrients, such as potassium, vitamin $\mathrm{C}$, vitamin $\mathrm{E}$ and folate (Agarwal, et al 2001). In addition to their micronutrient content, tomatoes, and their tomato-based products, also contain valuable phytochemicals or bioactive components, mainly phenolic compounds and carotenoids, such as lycopene. Phenolic compounds in tomatoes are mainly represented by flavanones (naringenin glycosilated derivatives) and flavonols (quercetin, rutin and kaempferol glycosilated derivatives) (Stewart et al, 2000, ; Le Gall et al, 2003, Bahorun et al, 2004; Slimestad et al 2008).

Principal products obtained by tomato processing are whole peeled tomatoes, chopped tomatoes, tomato puree, tomato paste, tomato juices, etc., differently classified based on laws in force in every country. Tomato puree is intended for sauce preparation and usually obtained starting from tomato sieving and then partially concentrated; its soluble solid content is less than $12^{\circ}$ Brix, net of the added salt, while for tomato paste, the dry matter content is more than $12 \%$. In USA, tomato pastes are divided into four non-mandatory typologies: light $\left(24-28^{\circ}\right.$ Brix $)$, medium $\left(28-32^{\circ}\right.$ Brix $)$, heavy $\left(32-39.3^{\circ}\right.$ Brix), and extra-heavy (more than39. $3^{\circ}$ Brix) (Primavesi et al 2011).The consumer demand for minimally processed products of high quality has increased remarkably last years. Preferences shift towards fresh, healthy and rich flavour ready-to-eat foods with enhanced shelf life. Besides microbial safety, important quality aspects of such tomato products are colour, flavour, and consistency (Hayes et al 1998). In tomato products, an important reaction is the degradation of the red pigment lycopene during thermal process, resulting in changes of the colour (Rodrigo et al 2007). Consistency of tomato products refers to their viscosity and the ability of their solid portion to remain in suspension throughout the shelf-life of the product. The consistency of tomato products is strongly affected by the composition of the pectin (Hsu et al, 2008).

Colour is probably the first quality factor judged by tomato product consumers. Thus, an attractive deep red colour is a major quality attribute for tomato products (Thakur et al. 1996, Garcia \& Barrett, 2006). Among the parameters analyzed for the assessment of tomato quality, $\mathrm{pH}$ is very important because acidity influences

\footnotetext{
${ }^{1}$ Food Science and Technology Dept., Fac. of Agric., Alex. Univ., 21545-El-Shatby, Alexandria, Egypt

Received November 04, 2013, Accepted December 25, 2013
} 
the thermal processing conditions required for producing safe products (Mckee, et al 2003, Anthon $\&$ Barrett, 2010).

In general, adequate heat processing is given to tomato paste to achieve commercial sterility (Speck 1984), but sub- sequent abusive post-process handling/storage may lead to undesirable microbiological changes (Anon, 1980). The objective of the present study therefore was to evaluate the physical, chemical, and microbiological properties of tomato concentrate products that are locally consumed in Egypt.

\section{MATERIALIS AND METHODS}

\section{Samples}

The twenty five brands of concentrated tomato puree distributed for consumption in Egypt were purchased from local markets, Alexandria, Egypt during November '2012. Fourteen brands of concentrated tomato puree are sold in sealed jars, five brands are sold in sachet and five brands are sold in cans. The products were kept sealed and refrigerated at $4^{\circ} \mathrm{C}$ until the time of analysis. All samples were stirred before placing a sample into the plastic jar with lids for the evaluation.

\section{Physicochemical analysis}

Physicochemical analysis including total soluble solids (TTS), pH, acidity, sodium chloride, ash, colour and consistency were determined. All determinations were carried out in triplicates.

The percentage of total soluble solids (TSS) was determined by using an digital refractometer (ATAGO, 0252985, Japan) according to Porretta (1993).

The $\mathrm{pH}$ of samples (mixed in distilled water at 1:2 ratio) was determined with a glass electrode $\mathrm{pH}$ meter (HANNA 351301, Romania) after standardization. (Efiuvwevwere \& Atirike, 1998).

Total titratable acidity(\%) as citric acid was determined by direct titration of $2 \mathrm{~g}$. of sample with $0.1 \mathrm{~N}$ sodium hydroxide using phenolphthalein as an indicator according to Ranganna (1986).

Sodium chloride content was determined according to the Moher method as described by Ranganna (1986). Five gm of sample were direct titrated with $(0.1 \mathrm{~N})$ silver nitrate solution using potassium chromate as indicator and calculated as $\%$ sodium chloride.

The ash content was determined according to the methods described in AOAC (2007).

Hunter $\mathrm{L}^{*}, \mathrm{a}^{*}$, and $\mathrm{b}^{*}$ parameters (colour) of concentrated tomato puree were measured by a Hunter Lab Colorimeter (Colourfelx, CX0558, USA). The redyellow ratio $\left(\mathrm{a}^{*} / \mathrm{b}^{*}\right)$ was reported to indicate the redness of tomato puree (Hsu, 2008).
Consistency of tomato concentrate samples were diluted to $12{ }^{\circ}$ Brix. Then, their consistencies were measured by Bostwick consistometer (Italy) at $25^{\circ} \mathrm{C}$. The results were reported as the distance traveled $(\mathrm{cm})$ in 30 seconds (Barrett, et al, 1998).

Microbiologica analysis

The Howard mould count was conducted according to the methods described in AOAC (2007).

Total plate count $(\mathrm{CFU} / \mathrm{g})$ was determined by using a Plate Count Agar (Difco, Kansas City, USA) after incubation at $25{ }^{\circ} \mathrm{C}$ for $48 \mathrm{hr}$. Yeasts and molds were determined with Malt Extract Agar (Difco, Kansas City, USA) acidified at $\mathrm{pH} 4.0$ after incubation at $25{ }^{\circ} \mathrm{C}$ for 72 hr. ( Efiuvwevwere \& Atirike, 1998 )

Statistical analysis

The results are presented as their mean values standard deviation (SD). The data were subjected to analysis of variance (ANOVA) using SAS software (2000). Least significant differences test (LSD) was performed to determine difference in means at $\mathrm{P} \leq 0.05$.

\section{RESULTS AND DISCUSSION}

\section{Physicochemical characteristics}

\section{Total soluble solids (TSS)}

Table (1) shows that the TSS values of fourteen concentrated tomato puree in jars ranged between 20 to $25 \%$. The TSS values of all brands were within the acceptable limits of Codex Alimentarius Commission (2007) and Egyptian Organization for Standardization and Quality (2005).Tables $(2,3)$ indicate that the TTS values of five sachet products ranged between 22 (sample 5) to $25 \%$ (samples $1 \& 4$ ) and five samples of concentrated tomato puree in cans from $18 \%$ (sample 4) to $30 \%$ ( sample 3). Processed tomato concentrate is the product prepared by concentrating the juice or pulp obtained from substantially sound, mature red tomatoes (Lycopersicum esculentum) strained or otherwise prepared to exclude the majority of skins, seeds and other coarse or hard substances in the finished product(Codex, 2007). According to the Egyptian Organization for Standardization and Quality (2005), tomato puree contains 8 to less than $18 \%$ of natural total soluble solids while, concentrated tomato puree contains 18 to less than $24 \%$ of natural total soluble solids and tomato paste, contains at least $24 \%$ of natural total soluble solids. The data revealed that significant differences were noted between the producing companies for each group of products.

\section{The $\mathrm{pH}$ value}

The $\mathrm{pH}$ values of the fourteen concentrated tomato puree in jars are shown in Table (1) all samples had $\mathrm{pH}$ values below 4.3. Also, the same results could be 
obtained from Table (2) and Table (3) for sachet and cans products. The $\mathrm{pH}$ values of all brands were within the acceptable limits of Codex (must be below 4.6) while Egyptian Organization for Standardization and Quality (2005) must be 4.3. Although statistical differences were detected, few practical differences were noted among brands. Mckee, et al (2003) found that nine red sauce products had $\mathrm{pH}$ values below 4.2. Among the parameters analyzed for the assessment of tomato quality, $\mathrm{pH}$ is very important because acidity influences the thermal processing conditions required for producing safe products. Although the $\mathrm{pH}$ of mature tomatoes may exceed 4.6, tomato products are generally classified as acid foods ( $\mathrm{pH} \leq 4.6$ ), which require moderate conditions of processing to control microbial spoilage and enzyme inactivation (Hobson and Grierson1993). Nevertheless, pH 4.4 is suggested (Monti, 1980) as the maximum desirable to avoid potential spoilage caused by thermophilic organisms, and $\mathrm{pH} 4.25$ as the optimum value for processing tomatoes (Monti 1980, Garcia \& Barrett, et al 2006).

\section{Titratable acidity}

Acidity of the fourteen tomato concentrated puree in jars ranged from $1.18 \%$ to $1.90 \%$ as citric acid from Table(1) it can be seen that Brand 2 had the highest value of acidity. While from Table (2) the acidity ranged from $1.18 \%$ (sample 4 ) to $1.88 \%$ (sample 3 ) for five sachet tomato concentrated puree, Table (3) shows that acidity ranged between $1.09 \%$ and $2.05 \%$ for canned concentrated tomato puree. Tomato acidity varies continually during tomato development and maturation. Variation in tomato acidity is attributed to maturity stage rather than genetic differences (Stevens 1972b, Garcia \& Barrett, 2006) There is an inverse relationship between $\mathrm{pH}$ and titratable acidity, although sometimes the relationship is inaccurate (Stevens 1972a). Mean acidity of processing tomatoes is around 0.35\% (Thakur et al. 1996). Tomato product flavour depends on the accumulation and balance between sugar and organic acid content (Hobson \& Grierson 1993). The ratio of sugars to acids is something that may be used to indicate general flavour quality( Barrett, et al 2006).

\section{Sodium chloride content}

Sodium chloride content of jar samples under study ranged from $1.73 \%$ (sample No. 3) to $3.4 \%$ (samples No. $1 \& 6)$ as shown in Table (1). It ranged between $1.94 \%$ (sample No.4) to $3.7 \%$ (sample No.2) of samples in sachet while, from $0.84 \%$ (sample No. 2) to $2.81 \%$ (sample No.3). Because some samples contained more than 3\% sodium chloride, thus they do not comply with the Egyptian standard specifications (2005).

\section{Ash content}

Table (1) reveals that the ash contents of the fourteen concentrated tomato puree in jars under study ranged between $3.2 \%$ (sample No. 5) and 5.2\% (sample No. 1) also, ranged from $3.83-4.98 \%$ for five samples in sachet it can be seen that in Table (2). While Table (3) indicates that the ash contents of five samples in cans ranged from $2.48 \%$ (sample No. 4) to $6.06 \%$ (sample No. 3) and the sample No. 3 had the highest ash content.

\section{Colour}

Colour $\left(\mathrm{a}^{*} / \mathrm{b}^{*}\right.$ values $)$ of the fourteen tomato concentrated puree in jars ranged between 1.43 to 2.31as shown in Table (1) and ranged from 1.51-2.11 for products in sachet (Table 2) while, Table (3) indicates that the range was from1.67 to 2.09 for samples in cans. Colour is probably the first quality factor judged by tomato product consumers. Thus, an attractive deep red colour is a major quality attribute for tomato products (Thakur et al. 1996). Red-yellow ratio $\left(\mathrm{a}^{*} / \mathrm{b}^{*}\right)$, indicating the redness of tomato products are an $a^{*} / b^{*}$ ratio of 1.90 or greater represents a first quality product in terms of colour and an $\mathrm{a}^{*} / \mathrm{b}^{*}$ ratio of less than 1.80 means that the tomato products may be unacceptable for inclusion in products where a bright red colour is desired (Hayes et al., 1998). The result of a low $\mathrm{a}^{*} / \mathrm{b}^{*}$ value represented an orange to brown colour due to the breakdown of lycopene and formation of Maillard reaction products by the intensive heat treatment (Shi \& Le Maguer, 2000; Krebbers et al, 2003, Hsu, 2008). On this basis, the worst samples in this respect were sample No. 11in jars, sample No.3 in sachet and sample No. 1 in cans.

\section{Consistency}

Table (1) reveals that the Consistency in jar products ranged between $5.9 \mathrm{~cm} / 30 \mathrm{~s}$ to $11.9 \mathrm{~cm} / 30 \mathrm{~s}$ while, from $7.45 \mathrm{~cm} / 30 \mathrm{~s}$ to $12.67 \mathrm{~cm} / 30 \mathrm{~s}$ of the samples in sachet and from $5.70 \mathrm{~cm} / 30 \mathrm{~s}$ to $9.01 \mathrm{~cm} / 30 \mathrm{~s}$ of the samples in can. Although second only to colour, consistency is probably the most important quality parameter considered in consumer acceptability of tomato products. Consistency is also important for several unit operations (heating, pumping, mixing) involved in tomato processing (Sharma et al.1996). Consistency of tomato paste is typically determined using a Bostwick consistometer. U.S. Department of Agriculture grade C for tomato sauce establishes that tomato product flow should be less than $18 \mathrm{~cm} / 30 \mathrm{~s}$ (USDA1994). Bostwick consistency is a very quick empirical measurement used in tomato industry, to assess quality of tomato products. Smaller Bostwick values indicate a thicker, higher consistency tomato product; therefore, smaller numbers are preferable. Consistency of tomato products is 
dependent on the total solids content of tomato products, which include soluble solids (mainly sugars and organic acids) and insoluble solids (protein and polysaccharides such as pectins and hemicelluloses). Many investigators have found that tomato maturity has a considerable effect on consistency; more mature tomatoes tend to produce higher Bostwick values, for example, thinner, low quality paste. Other factors such as cultivar, growing location, processing conditions, solids, electrolytes and $\mathrm{pH}$ may affect consistency. Tomato cultivar may be the most important factor (Thakur et al. 1996, Boulekou, et al.2011).

\section{Microbiological evaluation}

The results in Table(4) indicate that, neither bacteria nor yeast and mold growth were detected in concentrated tomato puree. Brand 5 sachet concentrated tomato puree was the only exception exhibited both bacterial and mold/yeast growth, exhibiting an bacterial growth of $3.1 \times 10^{2} \mathrm{CFU} / \mathrm{g}$ and a mold/yeast growth 5.1 $\times 10^{2} \mathrm{CFU} / \mathrm{g}$. Among the variables that affect the microbial profile and shelf-stability of canned tomato products are the initial contamination of the raw materials (Anon. 1980; Robinson et al1994), the temperature-time process regime ( Jay 1986), and postprocess handling such as transportation and storage conditions (Banwart 1981; Lake et al. 1985). Also, from Table 4, it can be noted that the Howard mould count ranged from 12 to $20 \%$ for jar concentrated tomato puree, $16-24 \%$ for sachet concentrated tomato puree and12- 20\% for can concentrated tomato puree. As shown in Table 4, all the samples tested had a lower moulds content than the European Community (EC) limit (70\%) (2004). The Howard mould count, represents an index of the quality of the raw material used for the preparation of tomato puree. Maxima for moulds are applied in various countries (Egan et al, 1981).

Table 1. Physicochemical characteristics of concentrated tomato puree packed in jar

\begin{tabular}{|c|c|c|c|c|c|c|c|}
\hline \multirow[b]{2}{*}{ Samples } & \multicolumn{7}{|c|}{ Characters* } \\
\hline & TSS $\%$ & pH & Acidity \% & Salt $\%$ & Ash \% & $\begin{array}{c}\text { Colour } \\
\mathbf{a}^{* / b^{*}}\end{array}$ & $\begin{array}{c}\text { Consistency } \\
\text { cm/30s. }\end{array}$ \\
\hline 1 & $25.00^{\mathrm{a}}$ & $4.27^{\mathrm{b}} \pm 0.01$ & $1.58^{\mathrm{cd}} \pm 0.01$ & $3.40^{\mathrm{a}} \pm 0.01$ & $5.2^{\mathrm{a}} \pm 0.04$ & $1.79^{\mathrm{e}} \pm 0.01$ & $7.57^{\mathrm{g}} \pm 0.06$ \\
\hline 2 & $23.00^{\mathrm{d}}$ & $4.16^{\mathrm{f}} \pm 0.01$ & $1.9^{\mathrm{a}} \pm 0.10$ & $1.91^{\mathrm{i}} \pm 0.10$ & $3.53^{\mathrm{f}} \pm 0.06$ & $1.61^{\mathrm{i}} \pm 0.01$ & $9.60^{c} \pm 0.10$ \\
\hline 3 & $23.00^{\mathrm{d}}$ & $4.15^{\mathrm{g}} \pm 0.01$ & $1.68^{\mathrm{b}} \pm 0.02$ & $1.73^{\mathrm{h}} \pm 0.05$ & $3.52^{\mathrm{f}} \pm 0.08$ & $1.67^{\mathrm{g}} \pm 0.01$ & $8.65^{\mathrm{e}} \pm 0.15$ \\
\hline 4 & $24.75^{\mathrm{b}}$ & $4.20^{\mathrm{a}} \pm 0.17$ & $1.31^{\mathrm{gh}} \pm 0.04$ & $2.10^{\mathrm{h}} \pm 0.02$ & $4.53^{b} \pm 0.06$ & $1.93^{\mathrm{d}} \pm 0.02$ & $5.90^{\mathrm{i}} \pm 0.10$ \\
\hline 5 & $24.00^{\mathrm{c}}$ & $4.17^{\mathrm{f}} \pm 0.02$ & $1.40^{\mathrm{efg}} \pm 0.02$ & $2.19^{\mathrm{g}} \pm 0.02$ & $3.20^{\mathrm{g}} \pm 0.04$ & $2.05^{\mathrm{c}} \pm 0.01$ & $9.90^{\mathrm{b}} \pm 0.10$ \\
\hline 6 & $23.20^{\mathrm{d}}$ & $4.22^{\mathrm{cd}} \pm 0.01$ & $1.65^{\mathrm{bc}} \pm 0.01$ & $3.40^{\mathrm{a}} \pm 0.03$ & $4.18^{\text {cde }} \pm 0.04$ & $1.71^{\mathrm{f}} \pm 0.01$ & $6.45^{\mathrm{h}} \pm 0.05$ \\
\hline 7 & $22.50^{\mathrm{e}}$ & $4.21^{\mathrm{d}} \pm 0.01$ & $1.49^{\mathrm{de}} \pm 0.01$ & $2.69^{\mathrm{d}} \pm 0.01$ & $3.51^{\mathrm{f}} \pm 0.27$ & $1.45^{\mathrm{j}} \pm 0.01$ & $8.30^{\mathrm{f}} \pm 0.10$ \\
\hline 8 & $22.00^{\mathrm{f}}$ & $4.01^{\mathrm{i}} \pm 0.01$ & $1.58^{\mathrm{cd}} \pm 0.03$ & $2.47^{\mathrm{e}} \pm 0.03$ & $4.02^{\mathrm{e}} \pm 0.03$ & $1.67^{\mathrm{g}} \pm 0.01$ & $8.50^{\mathrm{ef}} \pm 0.10$ \\
\hline 9 & $21.00^{\mathrm{g}}$ & $4.12^{\mathrm{g}} \pm 0.02$ & $1.42^{\mathrm{ef}} \pm 0.02$ & $2.31^{\mathrm{f}} \pm 0.05$ & $3.26^{\mathrm{fg}} \pm 0.08$ & $1.81^{\mathrm{e}} \pm 0.01$ & $8.45^{\mathrm{ef}} \pm 0.05$ \\
\hline 10 & $23.00^{\mathrm{d}}$ & $4.19^{\mathrm{e}} \pm 0.01$ & $1.57^{\mathrm{cd}} \pm 0.02$ & $2.85^{\mathrm{c}} \pm 0.05$ & $4.45^{\mathrm{bc}} \pm 0.04$ & $1.64^{\mathrm{h}} \pm 0.01$ & $8.50^{\mathrm{ef}} \pm 0.10$ \\
\hline 11 & $20.00^{\mathrm{h}}$ & $4.23^{\mathrm{c}} \pm 0.01$ & $1.26^{\mathrm{hi}} \pm 0.01$ & $2.89^{c} \pm 0.01$ & $4.37^{\mathrm{bcd}} \pm 0.11$ & $1.43^{\mathrm{j}} \pm 0.01$ & $11.9^{\mathrm{a}} \pm 0.10$ \\
\hline 12 & $22.50^{\mathrm{e}}$ & $4.07^{\mathrm{h}} \pm 0.06$ & $1.45^{\mathrm{ef}} \pm 0.03$ & $2.94^{\mathrm{b}} \pm 0.04$ & $4.12^{\mathrm{de}} \pm 0.09$ & $2.15^{\mathrm{b}} \pm 0.01$ & $9.10^{\mathrm{d}} \pm 0.10$ \\
\hline 13 & $22.00^{\mathrm{f}}$ & $4.23^{\mathrm{c}} \pm 0.01$ & $1.36^{\mathrm{fg}} \pm 0.01$ & $2.05^{\mathrm{hi}} \pm 0.01$ & $4.44^{\mathrm{bc}} \pm 0.06$ & $2.31^{\mathrm{a}} \pm 0.01$ & $7.58^{\mathrm{g}} \pm 0.14$ \\
\hline 14 & $21.00^{\mathrm{g}}$ & $4.19^{\mathrm{e}} \pm 0.02$ & $1.18^{\mathrm{i}} \pm 0.02$ & $2.22^{\mathrm{h}} \pm 0.29$ & $4.14^{\mathrm{de}} \pm 0.07$ & $2.31^{\mathrm{a}} \pm 0.01$ & $8.55^{\mathrm{ef}} \pm 0.05$ \\
\hline range & $20.00-25.00$ & 4.01-4.27 & $1.18-1.90$ & $1.73-3.40$ & $3.20-5.20$ & $1.43-2.31$ & $5.90-11.9$ \\
\hline
\end{tabular}

Means in column not sharing the same letter are significantly different at $\mathrm{P} \leq 0.05^{*}$

TSS: Total soluble solids

Table 2. Physicochemical characteristics of concentrated tomato puree packed in sachet Characters*

\begin{tabular}{cccccccc} 
Samples & TSS\% & $\mathbf{p H}$ & Acidity \% & Salt \% & Ash \% & $\begin{array}{c}\text { Colour } \\
\mathbf{a}^{*} / \mathbf{b}^{*}\end{array}$ & $\begin{array}{c}\text { consistency } \\
\mathbf{c m} / \mathbf{3 0 s}\end{array}$ \\
\hline 1 & $25.00^{\mathrm{a}}$ & $4.19^{\mathrm{a}} \pm 0.01$ & $1.58^{\mathrm{b}} \pm 0.03$ & $2.85^{\mathrm{b}} \pm 0.05$ & $4.30^{\mathrm{c}} \pm 0.04$ & $1.56^{\mathrm{c}} \pm 0.01$ & $9.10^{\mathrm{b}} \pm 0.10$ \\
\hline 2 & $23.00^{\mathrm{c}}$ & $4.22^{\mathrm{a}} \pm 0.01$ & $1.53^{\mathrm{b}} \pm 0.03$ & $3.70^{\mathrm{a}} \pm 0.10$ & $4.98^{\mathrm{a}} \pm 0.03$ & $1.80^{\mathrm{b}} \pm 0.01$ & $12.67^{\mathrm{a}} \pm 0.15$ \\
\hline 3 & $23.50^{\mathrm{b}}$ & $4.19^{\mathrm{a}} \pm 0.01$ & $1.88^{\mathrm{a}} \pm 0.01$ & $1.98^{\mathrm{c}} \pm 0.01$ & $3.83^{\mathrm{d}} \pm 0.06$ & $1.51^{\mathrm{d}} \pm 0.01$ & $9.20^{\mathrm{b}} \pm 0.20$ \\
\hline 4 & $25.00^{\mathrm{a}}$ & $4.22^{\mathrm{a}} \pm 0.01$ & $1.18^{\mathrm{c}} \pm 0.01$ & $1.94^{\mathrm{c}} \pm 0.02$ & $4.29^{\mathrm{c}} \pm 0.07$ & $1.81^{\mathrm{b}} \pm 0.02$ & $8.25^{\mathrm{b}} \pm 0.35$ \\
\hline 5 & $22.00^{\mathrm{d}}$ & $4.19^{\mathrm{a}} \pm 0.02$ & $1.23^{\mathrm{c}} \pm 0.01$ & $2.1^{\mathrm{c}} \pm 0.01$ & $4.65^{\mathrm{b}} \pm 0.05$ & $2.11^{\mathrm{a}} \pm 0.01$ & $7.45^{\mathrm{c}} \pm 0.05$ \\
\hline Range & $22.00-25.00$ & $4.19-4.22$ & $1.18-1.88$ & $1.94-3.70$ & $3.83-4.98$ & $1.51-2.11$ & $7.45-12.67$ \\
\hline
\end{tabular}

Means in column not sharing the same letter are significantly different at $\mathrm{P} \leq 0.05^{*}$

TSS: Total soluble solids 
Table 3: Physicochemica characteristics of concentrated tomato puree packed in cans

\begin{tabular}{|c|c|c|c|c|c|c|c|}
\hline \multirow[b]{2}{*}{ Samples } & \multicolumn{7}{|c|}{ Characters* } \\
\hline & TSS\% & pH & $\begin{array}{l}\text { Acidity } \\
\text { g/100g }\end{array}$ & Salt \% & Ash\% & $\begin{array}{l}\text { Color } \\
\mathbf{a}^{* / b^{*}}\end{array}$ & $\begin{array}{c}\text { consistency } \\
\mathrm{cm} / \mathbf{3 0 s}\end{array}$ \\
\hline 1 & $28.50^{\mathrm{b}}$ & $4.16^{\mathrm{b}} \pm 0.01$ & $2.05^{\mathrm{a}} \pm 0.05$ & $2.06^{\mathrm{b}} \pm 0.04$ & $4.71^{\mathrm{b}} \pm 0.07$ & $1.67^{\mathrm{e}} \pm 0.02$ & $6.97^{\mathrm{c}} \pm 0.06$ \\
\hline 2 & $24.90^{\mathrm{c}}$ & $4.13^{\mathrm{c}} \pm 0.01$ & $1.09^{\mathrm{d}} \pm 0.01$ & $0.84^{\mathrm{d}} \pm 0.01$ & $2.57^{\mathrm{c}} \pm 0.04$ & $2.09^{\mathrm{a}} \pm 0.01$ & $5.70^{\mathrm{d}} \pm 0.10$ \\
\hline 3 & $30.00^{\mathrm{a}}$ & $4.11^{\mathrm{c}} \pm 0.01$ & $1.83^{\mathrm{b}} \pm 0.03$ & $2.81^{\mathrm{a}} \pm 0.01$ & $6.06^{\mathrm{a}} \pm 0.04$ & $1.98^{\mathrm{b}} \pm 0.01$ & $7.65^{b} \pm 0.05$ \\
\hline 4 & $18.00^{\mathrm{e}}$ & $4.11^{\mathrm{c}} \pm 0.01$ & $1.48^{\mathrm{c}} \pm 0.02$ & $1.20^{\mathrm{c}} \pm 0.04$ & $2.48^{\mathrm{c}} \pm 0.08$ & $1.97^{\mathrm{c}} \pm 0.02$ & $9.01^{\mathrm{a}} \pm 0.01$ \\
\hline 5 & $21.00^{\mathrm{d}}$ & $4.12^{\mathrm{a}} \pm 0.01$ & $1.53^{\mathrm{c}} \pm 0.01$ & $2.07^{\mathrm{b}} \pm 0.01$ & $4.77^{\mathrm{b}} \pm 0.03$ & $1.76^{\mathrm{d}} \pm 0.01$ & $7.51^{\mathrm{b}} \pm 0.02$ \\
\hline Range & $18.00-30.00$ & $4.11-4.16$ & $1.09-2.05$ & $0.84-2.81$ & $2.48-6.06$ & $1.67-2.09$ & $5.70-9.01$ \\
\hline
\end{tabular}

Means in column not sharing the same letter are significantly different at $\mathrm{P} \leq 0.05^{*}$

TSS: Total soluble solids

Table 4. Microbiological analysis of concentrated tomato puree in different packages

\begin{tabular}{|c|c|c|c|}
\hline Samples & H.C\% & $\begin{array}{c}\text { Y\&M } \\
(\mathrm{CFU} / \mathrm{g})\end{array}$ & $\begin{array}{l}\text { T.P.C } \\
\text { (CFU/g) }\end{array}$ \\
\hline \multicolumn{4}{|c|}{ Jars } \\
\hline 1 & 12 & N.D. & N.D. \\
\hline 2 & 12 & N.D. & N.D. \\
\hline 3 & 12 & N.D. & N.D. \\
\hline 4 & 12 & N.D. & N.D. \\
\hline 5 & 16 & N.D. & N.D. \\
\hline 6 & 12 & N.D. & N.D. \\
\hline 7 & 20 & N.D. & N.D. \\
\hline 8 & 16 & N.D. & N.D. \\
\hline 9 & 16 & N.D. & N.D. \\
\hline 10 & 12 & N.D. & N.D. \\
\hline 11 & 20 & N.D. & N.D. \\
\hline 12 & 16 & N.D. & N.D. \\
\hline 13 & 12 & N.D. & N.D. \\
\hline \multirow[t]{2}{*}{14} & 16 & N.D. & N.D. \\
\hline & \multicolumn{2}{|c|}{ Sachet } & \\
\hline 1 & 16 & N.D. & N.D. \\
\hline 2 & 20 & N.D. & N.D. \\
\hline 3 & 16 & N.D. & N.D. \\
\hline 4 & 16 & N.D. & N.D. \\
\hline \multirow[t]{2}{*}{5} & 24 & $5.1 * 10^{2}$ & $3.1 * 10^{2}$ \\
\hline & \multicolumn{2}{|c|}{ Cans } & \\
\hline 1 & 12 & N.D. & N.D. \\
\hline 2 & 12 & N.D. & N.D. \\
\hline 3 & 16 & N.D. & N.D. \\
\hline 4 & 20 & N.D. & N.D. \\
\hline 5 & 16 & N.D. & N.D. \\
\hline
\end{tabular}

H.C.:Howard mould count

Y\&M: Yeast and mould

T.P.C. Total plate count

N.D: Not detected

In a conclusion, the commercial brands of concentrated tomato puree locally consumed in Egypt are compatible in general with the standard specifications recommended by the Egyptian standard specifications and Codex. However, analysis of some samples revealed different values from that mentioned on the labels and there were significant differences between the various companies. 


\section{REFERENCES}

Agarwal, A., Shen, H., Agarwal, S., and Rao, A. V. (2001). Lycopene content of tomato products: its stability, bioavailability and in vivo antioxidant properties. Journal of Medicinal Food, 4: 9-15.

Anon. (1980). Microbial Ecology of Foods, Vol. II, Food Commodities. New York: Academic Press.

Anthon, G. E. and Barrett, D. M. (2010). Changes in tomato paste during storage and the effects of heating on consistency of reconstituted tomato paste. Journal of Texture Studies, 41: 262-278.

AOAC. (2007). Official Methods of Analysis of the AOAC International $18^{\text {th }} \mathrm{Ed}$. Gaithersburg, , USA

Augusto, P. E. D., Falguera, V., Cristianini, M. and Ibarz, A. (2011). Rheological behavior of tomato juice: steady-state shear and time-dependent modeling. Food and Bioprocess Technology. doi:10.1007/s11947-010-04728.

Bahorun, T., Luximon-Ramma, A., Crozier, A. and Aruoma, O. I. (2004). Total phenol, flavonoid, proanthocyanidin and vitamin $\mathrm{C}$ levels and antioxidant activities of Mauritian vegetables. Journal of the Science of Food \& Agriculture, 84:1553-1561.

Banwart, J. (1981). Basic Food Microbiology. Westport: Avi Publishing Co.

Barrett, D. M., Garcia, E. and Wayne, J. E. (1998). Textural modification of processing tomatoes. Critical Reviews in Food Science and Nutrition, 38(3): 173-258.

Barrett, D. M., Garcia, E. and Miyao, G. (2006). Defects and peelability of processing tomatoes. Journal of Food Processing and Preservation, 30: 37-45.

Boulekou, S., Mallidis, C., Petros S. Taoukis, P. S. and Stoforos, N. G. (2011). Quality evaluation of slightly concentrated tomato juice produced under high pressure conditions. Procedia Food Science, 1: 800 - 804.

Cantarelli P. R., Regitano-darce, M. A. B. and Palma E. R. (1993). Physicochemical characteristics and fatty acid composition of tomato seed oils from processing wastes. Scientia Agricola, 50:117-20.

Codex Alimentarius Commission. (2007). Joint FAO/WHO Food Standards Programme $30^{\text {th }}$ SessionRome, Italy, ALINORM 07/30/27.

Efiuvwevwere, B. J. O. and Atirike, O. I. E. (1998). Microbiological profile and potential hazards associated with imported and local brands of tomato paste in Nigeria. Journal of Applied Microbiology, 84: 409-416.

Egan, H., Kirk, R. S. and Sawyer, R. (1981) Pearson's Chemical Analysis of Foods. $8^{\text {th }}$ Ed. Longman Groupimited London. Pp 203-205.

Egyptian Organization for Standardization and Quality. (2005). Preserved tomato products, part-1, tomatoconcentrates, ES: 132-1.

European Community Common Position Codex Gommittee on Processed Fruits and Vegetables (2004) 22 Session, Washington D.C.
Garcia, E. and. Barrett, D. M. (2006). Evaluation of processing tomatoes from two Consecutive growing seasons: quality attributes, peelability and yield. Journal of Food Processing and Preservation, 30: 20-36.

Grieb, S. M. D., Theis, R. P., Burr, D., Benardot, D., Siddiqui, T. and Asal, N. R. (2009). Food groups and renal cell carcinoma: results from a case-control study. Journal of the American Dietetic Association, 109: 656667.

Hayes, W. A., Smith, P. G. and Morris, A. E. J. (1998). The production (lmportant) and quality of tomato concentrates. Critical Reviews in Food Science and Nutrition, 38(7): 537-564.

Hobson, G. and Grierson, D. (1993). Tomato. In Biochemistry of Fruit Ripening (G.B. Seymour, J.E. Taylor and G.A. Tucker, eds), Chapman \& Hall, London, U.K. pp. 405442.

Hsu, K (2008). Evaluation of processing qualities of tomato juice induced by thermal and pressure processing. LWT, 41: 450-459.

Hsu, K., Tan, F. and Chi, H. (2008). Evaluation of microbial inactivation and physicochemical properties of pressurized tomato juice during refrigerated storage. LWT, 41: 367-375.

Jay, J.M. (1986). Modern Food Microbiology, 3rd Ed. van Nostrand Co. New York

Krebbers, B., Matser, A. M., Hoogerwerf, S. W., Moezelaar, R., Momassen, M. M. M. and van den Berg, R.W.(2003). Combined high-pressure and thermal treatments for processing of tomato puree: evaluation of microbial inactivation and quality parameters. Innovations in Food Science and Emerging Technologies, 4: 377-385.

Lake, D.E., Graves, R.R., Lesniekski, R.S. and Anderson, J.E. (1985). Post-processing spoilage of low acid canned foods by mesophilic anaerobic spore-formers. Journal of Food Protection, 48: 221-226.

Le Gall, G., Dupont, M. S., Mellon, F. A., Davis, A. L., Collins, G. J. and Verhoeyen, M. E. (2003). Characterization and content of flavonoid glycosides in genetically modified tomato (Lycopersicon esculentum) fruits. Journal of Agricultural \& Food Chemistry, 51: 2438-2446.

Mckee, L.H. Christopher, J. and Bock, M.A. (2003). Quality evaluation of commercial chile-based salsas. Plant Foods for Human Nutrition, 58: 1-12.

Monti, L.M. 1980. The breeding of tomatoes for peeling. Acta Hortic. 100: 341-349.

Nisha, P., Singhal, R. S. and Pandit, A. B. (2011). Kinetic modelling of colour degradation in tomato puree (Lycopersicon esculentum L.). Food and Bioprocess Technology, 4:781-787.

Porretta, S. (1993). Analysis of sensory and physicochemical data on commercial tomato puree with pattern recognition techniques. Z Lebensm Unters Forsch, 197:531-536. 
Primavesi, L., Pravettoni, V., Brenna, O.V., Farioli, L., Elide, A., Pastorello, E.A. and Pompei, C. (2011). Influence of technological processing on the allergenicity of tomato products. Eur. Food Res. Technol., 232:631636.

Ranganna, S. (1986). Manual of Analysis and Quality Control for Fruit and Vegetable Products. Tata McGraw-Hill, New Delhi, India, Pp 941-975.

Robinson, T.P., Wimpenny, J.W.T. and Earnshaw, R.C. (1994). Modelling the growth of Clostridium sporogenes in tomato juice contaminated with mould. Letters in Applied Microbiology, 19: 129- 133.

Rodrigo, D., van Loey, A. and Hendrickx, M. (2007). Combined thermal and high pressure colour degradation of tomato pruee and strawberry juice. Journal of Food Engineering, 79: 553-560.

SAS (2000) SAS User, Guide. Version 4. Cary, NC: SAS Institute, USA.

Shao, D. Bartley, G. E. , Yokoyama, W. , Pan, Z. , Zhang, H. and Zhang, A . (2013). Plasma and hepatic cholesterollowering effects of tomato pomace, tomato seed oil and defatted tomato seed in hamsters fed with high-fat diets. Food Chemistry, 139: 589-596.

Sharma, S.K., Lemaguer, M., Liptay, A. and Poysa, V. (1996). Effect of composition on the rheological properties of tomato thin pulp. Food Res. Int., 29: 175179.

Shi, J., and Le Maguer, M.(2000). Lycopene in tomatoes: chemical and physical properties affected by food processing. Crit. Rev. in Biotech., 20: 293-334.

Slimestad, R., Fossen, T. and Verheul, M. J. (2008). The flavonoids of tomatoes. Journal of Agricultural \& Food Chemistry, 56: 2436-2441.
Speck, M.E. (1984) Compendium of Methods for the Microbiological Examinations of Foods, $2^{\text {nd }}$ Ed. Washington DC: American Public Health Association.

Stahl, W. and Sies, H. (2005). Bioactivity and protective effects of natural carotenoids. Biochimica Et Biophysica Acta-Molecular Basis of Disease, 1740: 101-107.

Stevens, M.A. (1972a). Relationship between components contributing to quality variation among tomato lines. J. Am. Soc. Hortic. Sci., 97: 70-73.

Stevens, M.A. (1972b). Citrate and malate concentrations in tomato fruits: Genetic control and maturational effects. J. Am. Soc. Hortic. Sci., 97: 655-658.

Stewart, A. J., Bozonnet, S., Mullen, W., Jenkins, G. I., Lean, M. E. J. and Crozier, A. (2000). Occurrence of flavonols in tomatoes and tomato-based products. Journal of Agricultural \& Food Chemistry, 48: 2663-2669.

Thakur, B.R., Singh, R.K. and Nelson, P. (1996). Quality attributes of processed tomato products: A review. Food Res. Int., 12: 375-401.

United States Department of Agriculture(USDA). (1994). United States standards for grades of tomato sauce. Federal Register. 59 FR52624. URL http://www.ams.usda.gov/standards/cntatos.pdf.

Vallverdú-Queralt, A. , Medina-Remón, A., Casals-Ribes, I. , Andres-Lacueva, C. , Waterhouse, A. L. E, and LamuelaRaventos, R. M. (2012). Effect of tomatoindustrial processing on phenolic profile and hydrophilic antioxidant capacity. LWT-Food Science and Technology, 47: $154-160$

Zhang, C. X., Ho, S. C., Chen, Y. M., Fu, J. H., Cheng, S. Z. and Lin, F. Y. (2009). Greater vegetable and fruit intake is associated with a lower risk of breast cancer among Chinese women. International Journal of Cancer, 125: 181-188. 


\section{الملخص العربي}

\section{التقييم الفيزوكيماوي والميكروبيولوجي لمركزات الطماطم المستهلكة في مصر}

منى حسن حسين بخيت

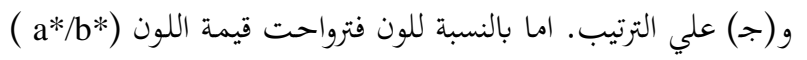

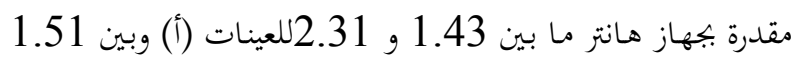

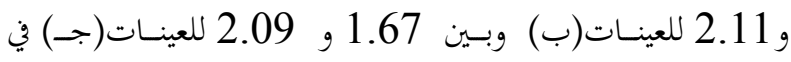

حسين ترواحست اللزوجـة مسن 5.90 إلي 11.90 ونسين 11.90 ومسن 7.45 إلي

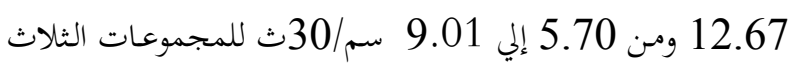

من العينات علي الترتيب ـ ولم يلاحظ أي نمو ميكروبي ما عدا عينة

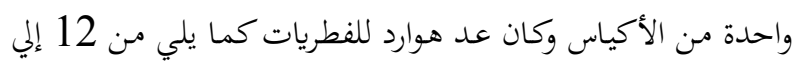

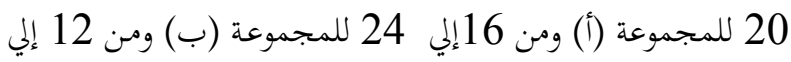

20

مما سبق نلاحظ أنه توجد فروق معنوية واضحة بين الشـركات

المنتجة كما يوجد في بعض الحالات عدم تطابق بين بيانات البطاقة

ونتائج التحليل.
اجريست هـــه الدراسـة بهـــف تقـــير الخــواص الفيزوكيميائيسة

والميكروبيولوجية لأربع وعشرين عينة من مركز الطماطم الموجودة في

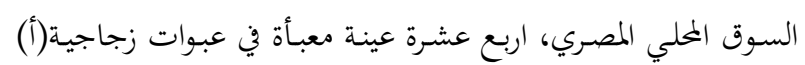

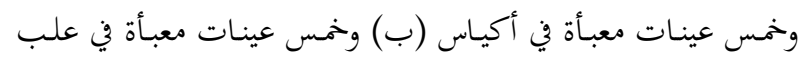

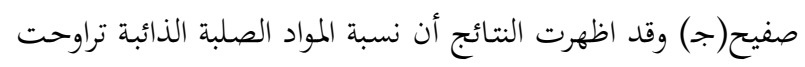

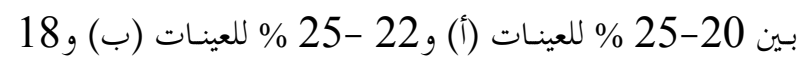

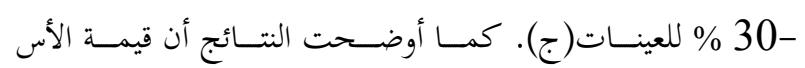

الهيدروجيني لجميع العينات تحت الدراسة كانت أقل مـ 4.3 بينما

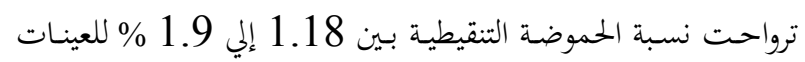

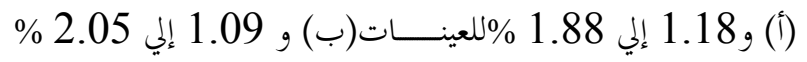
للعينات(ج).

وتراوحت نسب كلوريد الصوديوم من 1.73 إلي 3.40 و مـن

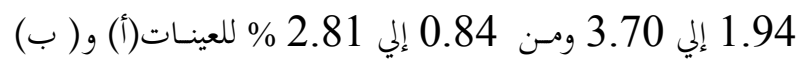

